Шекета Євгенія Юріївна кандидат економічних наук, викладач вищої категорії, завідувач кафедри фінансів, банківської справи та страхування, Івано-Франківський коледж Львівського національного аграрного університету, вул. Юності, 11, м. Івано-Франківськ, 76494, тел.: (0342) 55-47-14, https://orcid.org/0000-0001-7182-9447

\title{
ОСОБЛИВОСТІ БУХГАЛТЕРСЬКОГО ОБЛІКУ ТА ЗВІТНОСТІ НЕПРИБУТКОВИХ ОРГАНІЗАЦІЙ УКРАЇНИ
}

Анотація. В Україні все більшої популярності набуває діяльність неприбуткових установ і організацій, які створюються з метою забезпечення найпоширеніших проблем громадян соціального характеру та створення загальних суспільних благ задля добробуту всіх людей країни. Величезна кількість неприбуткових організацій у нашій країні взяла на себе виклики i соціальні проблеми суспільства, на які у держави не вистачає фінансування. Такого роду установи і організації діють в суспільстві у великій кількості, що свідчить про їх важливість, необхідність алгоритму їх реєстрації, організації та методології бухгалтерського обліку та звітності. У статті розкрито сутність поняття “неприбуткова організація”. Визначено перелік організацій, які належать до неприбуткових установ. Наведено перелік основних нормативноправових актів, які регулюють процес створення, ліквідації та діяльності неприбуткових установ. Сформовано алгоритм реєстрації неприбуткової організації у державних органах. Виокремлено основні критерії, яким слід відповідати неприбутковим організація для включення до Реєстру неприбуткових установ. Визначено перелік документів, які слід подати до Державної податкової інспекції для включення до Реєстру неприбуткових установ. Перелічено ряд способів, якими можна подати Запит на отримання витягу 3 Реєстру неприбуткових установ та організацій. Досліджено особливості ведення бухгалтерського обліку неприбутковими організаціями, а саме механізм відображення доходів та витрат згідно національних положень (стандартів) бухгалтерського обліку. Висвітлено процес здійснення господарської діяльності неприбуткової організації, необмеженість у виборі видів іiі діяльності та податковий контроль державних органів за спрямуванням (фінансуванням) витрат. Визначено перелік основних видів та форм фінансової і податкової звітності неприбуткових організацій до контролюючих органів, а також їх граничний термін подання.

Ключові слова: бухгалтерський облік, фінансова звітність, податкова звітність, неприбуткові організації, Реєстр неприбуткових установ і організацій. 
Sheketa Yevheniia Yuriivna Candidate of Economic Sciences, Lecturer of the highest category, Head of the Department of Finance, Banking and Insurance, Ivano-Frankivsk College of Lviv National Agrarian University, Yunosti St., 11, Ivano-Frankivsk, 76494, tel.: (0342) 55-47-14, https://orcid.org/0000-0001-7182-9447

\title{
PECULIARITIES OF ACCOUNTING AND REPORTING OF NON-PROFIT ORGANIZATIONS OF UKRAINE
}

\begin{abstract}
The activities of non-profit institutions and organizations, which are created to ensure the most common problems of citizens of a social nature and create common public goods for the welfare of all people, are becoming increasingly popular in Ukraine. A large number of non-profit organizations in our country have taken on the challenges and social problems of society, for which the state lacks funding. Such institutions and organizations operate in society in large numbers, which indicates their importance, the need for an algorithm for their registration, organization and methodology of accounting and reporting. The article reveals the essence of the concept of "non-profit organization". The list of organizations that belong to non-profit institutions is determined. The list of basic normative-legal acts regulating the process of creation, liquidation and activity of non-profit institutions is given. The algorithm of registration of the non-profit organization in state bodies is formed. The main criteria to be met by non-profit organizations for inclusion in the Register of non-profit institutions are identified. The list of documents that should be submitted to the State Tax Inspectorate for inclusion in the Register of non-profit institutions has been determined. The following are a number of ways in which you can apply for an extract from the Register of Non-Profit Institutions and Organizations. The peculiarities of accounting by non-profit organizations, namely the mechanism of reflection of income and expenses according to national provisions (standards) of accounting are investigated. The process of economic activity of a nonprofit organization, unlimited choice of its activities and tax control of state bodies in the direction (financing) of expenditures are highlighted. The list of the main types and forms of financial and tax reporting of non-profit organizations to the controlling bodies, as well as their deadline for submission is determined.
\end{abstract}

Keywords: accounting, financial reporting, tax reporting, non-profit organizations, Register of non-profit institutions and organizations.

Постановка проблеми. Особливої гостроти та актуальності в Україні зараз набувають питання організації бухгалтерського обліку та звітності неприбуткових організацій (далі НПО), оскільки комерційний сектор економіки не в змозі вирішити велику кількість питань соціального характеру, які в геометричній прогресії зростають за останні десятиліття. Велика кількість проблем соціального характеру в нашій країні стала основою функціонування неприбуткових установ і організацій, в яких статутом передбачено мету, цілі, 
завдання та напрями їх діяльності. Роль НПО в нашій країні неоціненно велика, так як саме вони взяли на себе велику кількість проблем соціального характеру, які виникли у результаті війни на сході України, а також інші соціальні проблеми суспільства, які виникають через брак фінансових ресурсів i відсутності допомоги з боку як державної, так і місцевої влади. Саме тому питання організації бухгалтерського обліку у НПО $є$ важливою складовою їх функціонування, оскільки містить вичерпні фінансові відомості про організацію обліку суб’єкта господарської діяльності. Він базується на певних правилах визначення, класифікації та інтерпретування операцій чи подій, пов’язаних із діяльністю установи. Бухгалтерський облік $\epsilon$ вирішальним чинником ефективного управління неприбутковою організацією.

Аналіз останніх досліджень та публікацій. Питання бухгалтерського обліку та звітності неприбуткових організацій останнім часом привертає дедалі більше уваги вчених-економістів, оскільки нормативно-правові акти, що регулюють організацію та методологію бухгалтерського обліку суб'єктів господарської діяльності не містять окремих і чітких норм щодо ведення обліку неприбуткових організацій. Серед вітчизняних представників економічної науки різні аспекти власне бухгалтерського обліку простежуються у напрацюваннях Бутинця Ф., Гарної С., Гончара Г., Касич А., Макаренко А., Шарманської В. та інших. Особливостям бухгалтерського обліку та звітності неприбуткових організацій присвячені праці Залуніна В. Ф. та Макарової Г. С. [1], Малахової А. В. та Мартиненко О. В [2], Кравченко О. В. [3].

Метою дослідження $\epsilon$ формування особливостей функціонування бухгалтерського обліку неприбуткових установ і організацій України та процес їх звітування у державних органах 3 урахуванням всіх податкових новацій поточного року.

Постановка завдання. Для досягнення поставленої мети визначено наступні наукові завдання: дослідити механізм набуття статусу неприбуткової організації юридичними особами; проаналізувати основні нормативно-правові акти що регулюють процес ведення бухгалтерського обліку неприбуткових організацій в Україні; виокремити особливості складання та подання податкової звітності неприбутковими організаціями.

Для вирішення поставлених завдань було використано наступні методи: аналіз, синтез, узагальнення, індукція, аналогія, системний підхід.

Виклад основного матеріалу дослідження. Чіткого визначення поняття “неприбуткова (установа) організація" в чинному законодавстві України не існує. Цей термін вперше був введений Законом України "Про оподаткування прибутку підприємств” [4], який визначив ряд установ та організацій, що мають право на пільги в оподаткуванні податком на прибуток. У інших нормативних актах, що регулюють діяльність таких установ (організацій), як правило, прямо вказується, що неприбуткові організації здійснюють свою діяльність без мети отримання прибутку. 


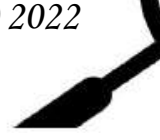

У Господарському кодексі України використовується поняття “некомерційне господарювання" - це самостійна систематична господарська діяльність, що здійснюється суб'єктами господарювання, спрямована на досягнення економічних, соціальних та інших результатів без мети одержання прибутку [5].

Цивільне законодавство України використовує поняття “непідприємницькі товариства”. Згідно ст. 85 Цивільного кодексу України “непідприємницькими товариствами” є товариства, які не мають на меті отримання прибутку для його подальшого розподілу між учасниками [6].

Згідно 3 пп. 133.4.1 п. 133.4 ст. 133 Податкового кодексу України неприбутковим підприємством, установою та організацією $є$ підприємство, установа та організація, що одночасно відповідає таким вимогам: утворена та зареєстрована в порядку, визначеному законом, що регулює діяльність відповідної неприбуткової організації; установчі документи якої містять заборону розподілу отриманих доходів (прибутків) або їх частини серед засновників (учасників), членів такої організації, працівників (крім оплати їхньої праці, нарахування єдиного соціального внеску), членів управління та інших пов'язаних з ними осіб; установчі документи якої передбачають передачу активів одній або кільком неприбутковим організаціям відповідного виду або зарахування до доходу бюджету у разі припинення юридичної особи (у результаті їі ліквідації, злиття, поділу, приєднання або перетворення); внесена контролюючим органом до Реєстру неприбуткових установ та організацій [7].

До неприбуткових організацій належать: бюджетні установи; громадські об’єднання, політичні партії, творчі спілки, релігійні організації, благодійні організації, пенсійні фонди; спілки, асоціації та інші об’єднання юридичних осіб; житлово-будівельні кооперативи, дачні, садівничі та гаражні кооперативи; ОСББ, асоціації власників жилих будинків; професійні спілки, їх об’єднання та організації профспілок, а також організації роботодавців та їх об'єднання; сільськогосподарські обслуговуючі кооперативи та інші юридичні особи, діяльність яких відповідає вимогам п. 133.4 Податкового кодексу України.

До неприбуткових організацій належать установи та організації, які відповідають вимогам п. 133.4 Податкового кодексу України. У такому разі для цілей ПКУ вони не $є$ платниками податку на прибуток. Неприбуткові організації у своїй діяльності повинні відповідати ряду вимог. По-перше, така організація повинна бути створена відповідно до свого профільного законодавства. По-друге, установчі документи обов'язково повинні містити положення про заборону розподілу доходів (прибутків) між членами, засновниками (не стосується бюджетних установ). По-третє, в статуті повинно бути передбачено твердження, що у разі ліквідації активи передаються такій же організації чи бюджету (не стосується об'єднань співмешканців багатоквартирних будинків, житлово-будівельних кооперативів та бюджетних установ). По-четверте, такі юридичні особи повинні бути включенні 
Державною податковою інспекцією за місцем реєстрації у Реєстр неприбуткових установ та організацій. 3 вищенаведених вимог можна зробити висновок, що розподіл доходів (прибутків) головна перешкода на шляху включення такого суб'єкта господарювання до Реєстру для перебування в числі неприбуткових організацій згідно Податкового кодексу України.

Порядок ведення Реєстру неприбуткових установ та організацій, включення неприбуткових підприємств, установ та організацій до Реєстру та виключення з Реєстру затверджений постановою Кабінету Міністрів України від 13.07.2016 р. № 440 [8]. Згідно п. 4 та п. 6 Порядку № 440 і пп. 133.4.1 ПКУ Новоствореній організації, яка не має на меті отримання прибутку, важливо встигнути протягом 10 днів 3 дня державної реєстрації подати документи (зокрема заяву за формою 1-РН) для включення в Реєстр неприбуткових установ та організацій, тоді неприбутківцем (тобто неплатником податку на прибуток) вона буде 3 дати реєстрації в Єдиному державному реєстрі. Строк розгляду заяви податковими органами 3 робочі дні.

Якщо не встигнути у цей 10 денний строк, то, з дати реєстрації у Єдиному державному реєстрі до дати включення у Реєстр неприбуткових установ та організацій, ця організація буде звичайним платником податку на прибуток, i лише 3 дати включення у Реєстр неприбуткових установ та організацій неплатник податку на прибуток (неприбутковою організацією).

Для реєстрації безсумнівно треба відповідати згаданим вище вимогам, зокрема щодо установчих документів та подати комплект документів для включення у Реєстр:

- заяву за формою № 1-РН (додаток 1 до Порядку № 440), підписану курівником або представником організації та скріплені печаткою (за наявності);

- копії установчих документів неприбуткової організації.

3 переліком неприбуткових установ (організацій) включених до Реєстру неприбуткових установ та організацій можна ознайомитись у відкритій та приватній частинах Електронного кабінету, розміщеного на офіційному вебпорталі Державної фіскальної служби України (https://cabinet.tax.gov.ua). Достатньо здійснити пошук за кодом ЄДРПОУ або найменуванням неприбуткової організації.

Запит про отримання витягу з Реєстру неприбуткових установ і організацій можна подати:

- особисто представником неприбуткової організації чи уповноваженою на це особою;

- надіслати поштою контролюючому органу за основним місцем обліку неприбуткової організації;

- засобами електронного зв'язку в електронній формі.

За запитом неприбуткової організації контролюючий орган надає їй безоплатно протягом 3 робочих днів, що настають за днем отримання такого запиту, витяг з Реєстру за формою згідно з додатком 4, який містить відомості 
про неприбуткову організацію, визначені п. 11 Порядку № 440, або повідомлення про відсутність відомостей у Реєстрі за формою згідно 3 додатком 5.

Витяг містить відомості з Реєстру неприбуткових установ та організацій, актуальні на дату та час його формування, та $є$ чинним до внесення змін до Реєстру в частині відомостей, що стосуються зазначеної неприбуткової організації.

Доходи (прибутки) неприбуткової організації використовуються виключно для фінансування видатків на утримання такої неприбуткової організації, реалізації мети (цілей, завдань) та напрямів діяльності, визначених іï установчими документами.

Згідно ст. 86 Цивільного кодексу України неприбутковим організаціям не заборонено окрім своєї основної неприбуткової діяльності, здійснювати й іншу діяльність (підприємницьку), якщо ця діяльність відповідає цілям, для яких вони були створені, i сприяє їх досягненню. Податковий кодекс України також не обмежує види діяльності, від яких неприбуткова організація може отримувати дохід, а обмежує тільки напрям його використання, тому, обов’язково слід зазначити можливість здійснення конкретного виду діяльності у статуті неприбуткової організації чи інших установчих документах.

Згідно Закону України “Про бухгалтерський облік та фінансову звітність в Україні” [9] будь які операції неприбуткової організації в обов'язковому порядку підлягають оформленню первинними документами. У ході здійснення господарської діяльності неприбуткової організації важливо не який дохід вона отримує (звісно такі доходи повинні отримуватися від діяльності яка відбувається у рамках закону та передбачена статутними документами такої організації), тут головний i ключовий акцент, на який i звертають увагу контролюючі органи, - на які цілі (статутні чи нестатутні) спрямовано цей дохід. Витрати на фінансування видатків на утримання такої неприбуткової організації, реалізацію мети (цілей, завдань) та напрямів діяльності, визначених iï установчими документами і є цільовими, тобто статутними витратами.

Неприбутковим організаціям заборонено розподіляти доходи (прибутки) між засновниками, членами таких організацій, працівниками (крім оплати їхньої праці, нарахування ССВ), членами органів управління та іншими пов’язаним 3 ними особами.

Здійснення господарської діяльності, спрямованої на отримання прибутку, класифікується як підприємництво (ст. 42 Господарського кодексу України [5]) i не відповідає сутності поняття некомерційної діяльності неприбуткових установ. Таким чином, неприбуткова організація, яка здійснює господарську діяльність на комерційній основі, набуває характеру підприємницької діяльності, і до неї застосовуються положення Господарського кодексу України та інших законів, якими регулюється підприємництво. Така організація не 
підпадає під визначення неприбуткової організації і підлягає виключенню 3 Реєстру неприбуткових установ та організацій.

Згідно П(С)БО 15 “Дохід” [10] та П(С)БО “Витрати” [11] неприбуткові організації при відображенні доходів та витрат використовують метод нарахувань. Він передбачає, що доходи i витрати відображають у бухгалтерському обліку та фінансовій звітності у момент їх виникнення, незалежно від дати надходження або сплати грошових коштів. Тобто результати операцій визнаються, коли вони відбуваються, а не тоді, коли отримуються або сплачуються за них кошти чи їх еквіваленти. Господарські операції повинні бути відображені в облікових регістрах у тому звітному періоді, в якому вони були здійснені.

У неприбуткової організації у бухгалтерському обліку може виникнути як прибуток так і збиток, не обов'язково все закриється у нуль. Тут важливо усвідомлювати, що усе що надходить неприбутковій організації (у т. ч. й те, що вона заробляє від своєї господарської діяльності) йде на фінансування іï діяльності. Тобто цілей отримання прибутку вона не ставить i розподіляти його між засновниками, членами організації не збирається, оскільки отримання прибутку не мета іiі діяльності. Але цілком можливо, що у якомусь періоді доходи перевищать витрати (тобто буде позитивна різниця між доходами та витратами), і витратяться вони лише в наступному періоді, от і можливо, що за якийсь період i виникне у бухгалтерському обліку прибуток. Чи навпаки витрати уже є, а фінансування на їх покриття прийде пізніше у наступних звітних періодах.

Як і всі юридичні особи, неприбуткові організації зобов'язані подавати фінансову звітність.

Таблицяя 1

\section{Основні види і форми звітності неприбуткових організацій} до державних органів

\begin{tabular}{|c|c|c|c|}
\hline Вид звітності & Форма (назва) звіту & $\begin{array}{c}\text { Державний } \\
\text { орган, якому } \\
\text { звітусться }\end{array}$ & Строк подачі звіту \\
\hline & $\begin{array}{c}\text { Баланс (ф. № 1-мс) та } \\
\text { Звіт про фінансові } \\
\text { результати (ф. № 2-мс) } \\
\text { для мікропідприємств. }\end{array}$ & \multirow{2}{*}{$\begin{array}{c}\text { Державна } \\
\text { служба } \\
\text { статистики } \\
\text { України } \\
\text { (квартальна, } \\
\text { річна звітність). }\end{array}$} & \multirow{2}{*}{$\begin{array}{c}\text { Не пізніше } 25 \text { числа } \\
\text { місяця наступного за } \\
\text { звітним кварталом. } \\
3 \text { 01.01.2022 р. не } \\
\text { пізніше } 30 \text { числа } \\
\text { місяця наступного за } \\
\text { звітним кварталом для } \\
\text { проміжної квартальної } \\
\text { фінансової звітності. } \\
\text { Не пізніше } 28 \text { лютого } \\
\text { наступного року за } \\
\text { звітним для річної } \\
\text { фінансової звітності. }\end{array}$} \\
\hline $\begin{array}{c}\text { Фінансова } \\
\text { звітність }\end{array}$ & $\begin{array}{c}\text { Баланс (ф. № 1-м) та } \\
\text { Звіт про фінансові } \\
\text { результати (ф. № 2-м) } \\
\text { для малих підприємств. }\end{array}$ & & \\
\hline
\end{tabular}


Журнал «Наукові інновачії та передові технологї̈

(Серія «Держсавне управління», Серія «Право»,

\begin{tabular}{|c|c|c|c|}
\hline $\begin{array}{c}\text { Податкова } \\
\text { звітність }\end{array}$ & $\begin{array}{c}\text { Звіт про використання } \\
\text { доходів (прибутків) } \\
\text { неприбуткової } \\
\text { організації одночасно з } \\
\text { пакетом річної } \\
\text { фінансової звітності }\end{array}$ & $\begin{array}{c}\text { Державна } \\
\text { фіскальна } \\
\text { служба України } \\
\text { (річна звітність). }\end{array}$ & $\begin{array}{c}\text { Не пізніше } 60 \text { днів по } \\
\text { закінченню звітного } \\
\text { року. }\end{array}$ \\
\hline $\begin{array}{c}\text { У разі } \\
\text { порушення } \\
\text { умов } \\
\text { неприбутковості }\end{array}$ & $\begin{array}{c}\text { Податкова декларація } 3 \\
\text { податку на прибуток } \\
\text { підприємств. } \\
\text { У разі порушення умов } \\
\text { неприбутковості згідно } \\
\text { п. 133.4 ПКУ разом } 3 \\
\text { декларацією з податку } \\
\text { на прибуток подається } \\
\text { і фінансова звітність. }\end{array}$ & $\begin{array}{c}\text { Державна } \\
\text { фіскальна } \\
\text { служба України. }\end{array}$ & $\begin{array}{c}\text { Протягом } 20 \text { днів за } \\
\text { місяцем порушення } \\
\text { треба подати Звіт про } \\
\text { використання доходів } \\
\text { (прибутків) } \\
\text { неприбуткової } \\
\text { організації разом з } \\
\text { фінансовою звітністю, } \\
\text { а далі щокварталу до } \\
\text { кінця року декларацію } \\
\text { з податку на прибуток } \\
\text { разом з фінансовою } \\
\text { звітністю у строк як } \\
\text { для квартальної } \\
\text { декларації, тобто } \\
\text { протягом } 40 \text { днів за } \\
\text { звітним кварталом. }\end{array}$ \\
\hline $\begin{array}{c}\text { Податкова } \\
\text { звітність з ССВ, } \\
\text { ПДФО та В3 (за } \\
\text { найманих } \\
\text { працівників) }\end{array}$ & $\begin{array}{c}\text { Податковий } \\
\text { розрахунок сум } \\
\text { доходу, нарахованого } \\
\text { (сплаченого) на } \\
\text { користь платників } \\
\text { податків - фізичних } \\
\text { осіб, і сум утриманого } \\
\text { з них податку, а також } \\
\text { сум нарахованого } \\
\text { єдиного внеску }\end{array}$ & $\begin{array}{c}\text { Державна } \\
\text { фіскальна } \\
\text { служба України } \\
\text { (квартальна } \\
\text { звітність). }\end{array}$ & $\begin{array}{c}\text { Протягом } 40 \\
\text { календарних днів після } \\
\text { закінчення звітного } \\
\text { кварталу. }\end{array}$ \\
\hline
\end{tabular}

* Побудовано автором на основі даних Податкового кодексу України [7].

За ч. 3 ст. 11 Закону України "Про бухгалтерський облік і фінансову звітність в Україні" [9] для мікропідприємств, малих підприємств, непідприємницьких товариств i представництв іноземних суб'єктів господарської діяльності, крім тих, що зобов'язані складати фінансову звітність за міжнародними стандартами, встановлюється скорочена за показниками фінансова звітність у складі Балансу та Звіту про фінансові результати.

Висновки. Процес реєстрації неприбуткової організації суттєво не відрізняється від процесу реєстрації суб'єкта господарювання - юридичної 
особи, проте, своя особливість тут все таки $є$ - це включення такої організації до Реєстру неприбуткових установ і організацій. Як з'ясувалося, отримання прибутку такою організацією не $є$ загрозою для позбавлення іï статусу неприбуткової організації як неплатника податку на прибуток. 3 Реєстру неприбуткових установ i організацій через це іiі не виключають, i неприбуткового статусу це іiі не позбавить. Головна і ключова умова, на яку i більшою мірою і звертає увагу податкова інспекція, щоб доходи (прибутки) неприбуткової організації були витрачені на мету, цілі діяльності такої організації і жодним чином не розподілялися між засновниками. Звісно ж, й отримання таких прибутків неприбутковою організацією має бути без порушення профільного законодавства та статутних документів.

\section{Лimepamypa:}

1. Залунін В.Ф. Особливості обліку та оподаткування неприбуткових організацій / В.Ф. Залунін, Г.С. Макарова // Глобальні та національні проблеми економіки. - 2016. Випуск 14. - С. 961-965.

2. Малахова А.В. Проблеми розвитку та особливості обліку в неприбуткових організаціях / А.В. Малахова, О.В. Мартиненко // Причорноморські економічні студії. 2019.- Випуск 48-3. - С. 160-165.

3. Кравченко О.В. Особливості обліку доходів і витрат неприбуткових організацій [Електронний ресурс] / О.В. Кравченко // Тези доповідей Всеукраїнської науково-практичної конференції “Актуальні проблеми науки та освіти молоді: теорія, практика, сучасні рішення” (10 грудня 2011 рік): за ред. В.С. Пономаренко, А.А. Пилипенко. - Х.: Фактор, 2011. C. 83-94. - Режим доступу: http://surl.li/axgit.

4. Закон України Про оподаткування прибутку підприємств: прийнятий 28 грудня 1994 року № 334/94-ВР. [Втратив чинність]. - [Електронний ресурс]. - Режим доступу: https://zakon.rada.gov.ua/laws/show/334/94-\%D0\%B2\%D1\%80\#Text.

5. Господарський кодекс України: станом на 06 жовтня 2021 року №436-IV. [Електронний ресурс]. - Режим доступу: https://zakon.rada.gov.ua/laws/show/436-15\#Text.

6. Цивільний кодекс України: станом на 28 жовтня 2021 року №435-IV. [Електронний pecypc]. - Режим доступу: https://zakon.rada.gov.ua/laws/show/435-15\#Text.

7. Податковий кодекс України: станом на 21 листопада 2021 року №2755-VI. [Електронний ресурс]. - Режим доступу: https://zakon.rada.gov.ua/laws/show/2755-17.

8. Постанова Кабінету Міністрів України Про затвердження Порядку ведення Реєстру неприбуткових установ та організацій, включення неприбуткових підприємств, установ та організацій до Реєстру та виключення з Реєстру: прийнята 13 липня 2016 року № 440. [Електронний ресурс]. - Режим доступу: https://zakon.rada.gov.ua/laws/show/440-2016$\%$ D0\%BF\#Text.

9. Закон України Про бухгалтерський облік та фінансову звітність в Україні: прийнятий 16 липня 1999 року № 996-XIV. - [Електронний ресурс]. - Режим доступу: https://zakon.rada.gov.ua/laws/show/996-14\#Text.

10. Національне положення (стандарт) бухгалтерського обліку 15 “Дохід”. Затверджене наказом Міністерства фінансів України від 29.11.99 року № 290. - [Електронний ресурс]. Режим доступу: https://zakon.rada.gov.ua/laws/show/z0860-99\#Text.

11. Національне положення (стандарт) бухгалтерського обліку 16 "Витрати". Затверджене наказом Міністерства фінансів України від 31.12 .99 року № 318. [Електронний ресурс]. - Режим доступу: https://zakon.rada.gov.ua/laws/show/z0027-00\#Text. 


\section{References:}

1. Zalunin, V.F., \& Makarova, H.S. (2016). Osoblyvosti obliku ta opodatkuvannya neprybutkovykh orhanizatsiy [Features of accounting and taxation of non-profit organizations]. Hlobalni ta natsionalni problemy ekonomiky - Global and national economic problems, 14, 961-965 [in Ukrainian].

2. Malakhova, A.V., \& Martynenko, O.V. (2019). Problemy rozvytku ta osoblyvosti obliku v neprybutkovykh orhanizatsiyakh [Problems of development and features of accounting in non-profit organizations]. Prychornomorski ekonomichni studiyi - Black Sea Economic Studies, 48-3, 160-165 [in Ukrainian].

3. Kravchenko, O.V. (2011). Osoblyvosti obliku dokhodiv i vytrat neprybutkovykh orhanizatsiy [Features of accounting for income and expenses of non-profit organizations]. V.S. Ronomarenkko (Eds.), Aktualni problemy nauky ta osvity molodi: teoriya, praktyka, suchasni rishennya - Current problems of science and education of youth: theory, practice, modern solutions: Proceedings of the All-Ukrainian Scientific and Practical Conference, (pp. 83-94). KH.: Faktor. Retrieved from: http://surl.li/axgit [in Ukrainian].

4. Zakon Ukrainy Pro opodatkuvannya prybutku pidpryyemstv pryiniatyi 28 hrudnya 1994 roku № 334/94-BP [Law of Ukraine On the taxation of corporate profits from December 28, 1994, № 334/94-VR]. zakon.rada.gov.ua. Retrieved from: https://zakon.rada.gov.ua/laws/show/334/94-\% D0\%B2\%D1\%80\#Text [in Ukrainian].

5. Hospodarskyi kodeks Ukrainy [Commercial CodeUkraine]. (2021, October 6, №436-IV). zakon.rada.gov.ua. Retrieved from: https://zakon.rada.gov.ua/laws/show/436-15\#Text [in Ukrainian].

6. Tsyvilnyi kodeks Ukrainy [Civil Code Ukraine]. (2021, October 28, №435-IV). zakon.rada.gov.ua. Retrieved from: https://zakon.rada.gov.ua/laws/show/435-15\#Text [in Ukrainian].

7. Podatkovyi kodeks Ukrainy: [Tax Code Ukraine]. (2021, November 21, №2755-VI). zakon.rada.gov.ua. Retrieved from: https://zakon.rada.gov.ua/laws/show/2755-17[in Ukrainian].

8. Postanova Kabinetu Ministriv Ukrainy Pro zatverdzhennya Poryadku vedennya Reyestru neprybutkovykh ustanov ta orhanizatsiy, vklyuchennya neprybutkovykh pidpryyemstv, ustanov ta orhanizatsiy do Reyestru ta vyklyuchennya z Reyestru pryiniata 13 lypnya 2016 roku № 440 [Resolution of the Cabinet of Ministers of Ukraine On Approval of the Procedure for Maintaining the Register of Non-Profit Institutions and Organizations, Inclusion of Non-Profit Enterprises, Institutions and Organizations in the Register and Exclusion from the Register from July 13, 2016, № 440]. zakon.rada.gov.ua. Retrieved from: https://zakon.rada.gov.ua/laws/show/440-2016-\%D0\%BF\#Text [in Ukrainian].

9. Zakon Ukrainy Pro bukhhalterskyy oblik ta finansovu zvitnist v Ukrayini pryiniatyi 16 lypnya 1999 roku№ 996-XIV [Law of Ukraine On accounting and financial reporting in Ukraine from July 16, 1999, № 996-XIV]. zakon.rada.gov.ua. Retrieved from: https://zakon.rada.gov.ua/ laws/show/996-14\#Text [in Ukrainian].

10. Natsionalne polozhennya (standart) bukhhalterskoho obliku 15 "Dokhid" [National Accounting Regulation (Standard) 15 "Income"]. Nakaz Ministerstva finansiv Ukrainy vid 29.11.99 № 290. zakon.rada.gov.ua. Retrieved from: https://zakon.rada.gov.ua/laws/show/z0860-99\#Text [in Ukrainian].

11. Natsionalne polozhennya (standart) bukhhalterskoho obliku 16 "Vytraty" [National Accounting Regulation (Standard) 16 "Expenses"]. Nakaz Ministerstva finansiv Ukrainy vid 31.12.99 № 318. zakon.rada.gov.ua. Retrieved from: https://zakon.rada.gov.ua/laws/show/ z0027-00\#Text [in Ukrainian]. 